accounted for by the perceived need for more intensive treatment for especially aggressive tumours, but in the absence of detailed histological reports on many of the cases this cannot be confirmed or refuted. Nevertheless, in a large proportion of cases nephrectomy and chemotherapy together evidently constitute sufficient treatment for the cure of infants with nephroblastoma. In the very youngest babies and some older patients nephrectomy alone has been followed by long-term disease-free survival.

We thank the many consultants and general practitioners who provided information on which this paper is based. We are grateful to Dr L M Kinnier Wilson for providing data from the Oxford Survey of Childhood Cancer, and to Mrs E M Roberts for her part in collecting the medical records and for secretarial help.

The Childhood Cancer Research Group is supported by the Department of Health and Social Security and the Scottish Home and Health Department. Collection of data was also supported by the Marie Curie Memorial Foundation.

\section{References}

1 Lennox EL, Stiller CA, Morris Jones PH, Kinnier Wilson LM. Nephroblastoma: treatment during 1970-3 and the effect on survival of inclusion in the first MRC trial. Br Med 7 1979; ii :567-9.

${ }^{2}$ Medical Research Council's Working Party on Embryonal Tumours in Childhood. Management of nephroblastoma in childhood. Arch Dis Child 1978;53:112-9.

3 Bond JV. Bilateral Wilms' tumour. Lancet 1975;ii:482-4.

${ }^{4}$ D'Angio GJ, Evans AE, Breslow N, et al. The treatment of Wilms' tumor. Cancer 1976;38:633-46.

${ }^{5}$ Leck I, Birch JM, Marsden HB, Steward JK. Methods of classifying and ascertaining children's tumours. Br $\mathcal{F}$ Cancer 1976;34:69-82.

6 Young JL, Heise HW, Silverberg E, Myers MH. Cancer incidence, survival and mortality for children under 15 years of age. New York: American Cancer Society, 1978.

7 Lemerle J, Tournade M-F, Gerard-Marchant R, et al. Wilms' tumor: natural history and prognostic factors Cancer $1976 ; 37: 2557-66$.

8 Bishop HC, Tefft M, Evans AE, D'Angio GJ. Survival in bilateral Wilms' tumor-review of 30 National Wilms' Tumor Study cases. 7 Pediatr Surg 1977;12:631-8.

(Accepted 28 September 1980)

\title{
Effect of guar crispbread with cereal products and leguminous seeds on blood glucose concentrations of diabetics
}

\author{
DAVID J A JENKINS, THOMAS M S WOLEVER, RODNEY H TAYLOR, HELEN M BARKER, \\ HASHMEIN FIELDEN, ALEXANDRA L JENKINS
}

\section{Summary and conclusions}

To compare the effect on blood glucose concentrations of guar incorporated into crispbreads with that of unprocessed high-fibre foods groups of four to six diabetics took a total of seven test breakfasts on separate days. By comparison with a breakfast of wholemeal bread and cheese, guar crispbread combined with bread reduced the area under the glucose response curve to $51 \%(p<0.05)$; bread and soya beans reduced the area to $65 \%(p<0.05)$ guar crispbread with soya beans to $25 \%(p<0.002)$; and soya beans with lentils to $29 \%(p<0.002)$. Porridge and cornflake breakfasts showed no difference.

The favourable results with leguminous seeds may not make such meals more acceptable than meals of guar products, but a combination of leguminous seeds and guar may allow smaller and more acceptable amounts of both to be used.

\footnotetext{
Department of the Regius Professor of Medicine, Radcliffe Infirmary, Oxford

DAVID J A JENKINS, DM, research associate

University Laboratory of Physiology, Oxford

THOMAS M S WOLEVER, MSC, research fellow

ALEXANDRA L JENKINS, research associate
Department of Gastroenterology, Central Middlesex Hospital, London NW10
RODNEY H TAYLOR, MRCP, Wellcome senior research fellow
HELEN M BARKER, BSC, SRD, research dietitian
HASHMEIN FIELDEN, SRN, research sister

\section{Introduction}

Studies on the use of purified fibre preparations in treating diabetes have often prompted comments unsupported by fact that using natural foods may be an effective and more palatable approach to this problem. ${ }^{12}$ To identify such foods $50-\mathrm{g}$ carbohydrate portions of a wide range of foods were taken by groups of healthy volunteers and the effect on the blood glucose response noted. ${ }^{3}$ These foods were then divided into two groups according to whether they caused small or large rises in blood glucose concentration. Foods were selected from each group and taken as breakfasts by diabetic volunteers so that their effects on blood glucose concentration could be studied and compared with the effect of a purified fibre product, guar crispbread. We report here the results.

\section{Methods}

Six diabetics (four women, two men; mean age $43+$ SEM 5 years; $99 \pm 3 \%$ ideal body weight; five receiving insulin 16-60 U/day and one controlled by diet alone) who had previously participated in a study testing the effect of guar and high-fibre foods on diabetic control were interested in testing the effect on their own blood glucose concentrations of taking meals of different composition and comparing this with the effect of guar. The food used had in earlier studies resulted in either large or small postprandial blood glucose responses in normal volunteers. ${ }^{3}$

The group met regularly on one or two Saturday mornings each month over four and a half months to test breakfasts in which a carbohydrate content equivalent to each subject's normal breakfast was derived from the following: wholemeal bread (88 SEM $13 \mathrm{~g}$ ) wholemeal bread $(46 \pm 8 \mathrm{~g})$ and guar crispbreads $(7 \pm 1$ crispbread) wholemeal bread $(46 \pm 8 \mathrm{~g})$ and soya beans $(91 \pm 11 \mathrm{~g})$; guar crispbread $(7 \pm 1$ crispbreads) and soya beans $(96 \pm 18 \mathrm{~g})$; soya beans $(75 \pm 6 \mathrm{~g})$ and lentils $(41 \pm 8 \mathrm{~g})$; cornflakes $(22 \pm 5 \mathrm{~g})$ and wholemeal bread $(45 \pm$ $10 \mathrm{~g})$; or porridge oats $(26 \pm 6 \mathrm{~g})$ and wholemeal spaghetti $(27 \pm 6 \mathrm{~g})$ 
Edam, Cheddar, and cottage cheeses were used to balance the fat and protein of the guar and leguminous-seed meals, which also included $120 \mathrm{~g}$ tomato and $500 \pm 40 \mathrm{ml}$ tea made with $50 \mathrm{ml}$ milk. The cereal breakfasts contained less fat and protein, the fat being balanced by added butter in the cornflake breakfast. Table I shows the composition of the breakfasts calculated with food tables. ${ }^{4}$

After overnight fasts the subjects took their usual morning insulin doses at the same time before each breakfast. The meal was eaten over 15-20 minutes. Finger-prick blood samples were taken for glucose analysis $^{5}$ at $0,30,60,90,120$, and 180 minutes. Some results on two of the meals (wholemeal bread and cheese, and mixed lentils and soya beans) have been reported. ${ }^{6}$

Results were expressed as means \pm SEM and the significances of differences calculated with Student's $t$ test for paired data.

The study was approved by the ethical committee of the Brent Area Health Authority.

\section{Results}

All the meals were well received, and no subject had difficulty in eating them in the prescribed time. The fat and protein in the wholemeal bread, wholemeal bread and crispbread, wholemeal bread and soya bean, and soya bean and lentil meals were balanced as closely as possible, the range of protein in the four meals being $35.4 \pm 2.3$ to $38.4+3 \cdot 19 \mathrm{~g}$ and of fat $15 \cdot 6 \pm 1.0$ to $18 \cdot 6 \pm 1.8 \mathrm{~g}$. The combination of soya beans and crispbread resulted in an increased intake of protein of $54.5 \pm 8 \cdot 2 \mathrm{~g}$ and of fat $19 \cdot 4 \pm 2.9 \mathrm{~g}$. The cornflakes and porridge breakfasts, though of the same composition as each other, contained less protein $(9 \cdot 5 \pm 0.5 \mathrm{~g}$ and $10 \cdot 2 \pm 0.9 \mathrm{~g}$ respectively) and fat $(6.4 \pm 0.5 \mathrm{~g}$ in both meals) than the other meals (table I).

Before each meal the ranges of mean fasting blood glucose concentrations $(10 \cdot 3 \pm 2 \cdot 1$ to $12 \cdot 9 \pm 2 \cdot 7 \mathrm{mmol} / 1 ; 185 \pm 38$ to $232 \pm 49$ soya beans and lentils $(29 \pm 11 \%, \mathrm{p}<0.002)$, wholemeal bread and guar crispbread $(51 \pm 16 \%, \mathrm{p}<0.05)$, and wholemeal bread and soya beans $(65+13 \%, \mathrm{p}<0.05)$. The porridge and cornflake breakfasts were not significantly different from wholemeal bread $(108 \pm 30 \%$ and $95 \pm 49 \%$ respectively).

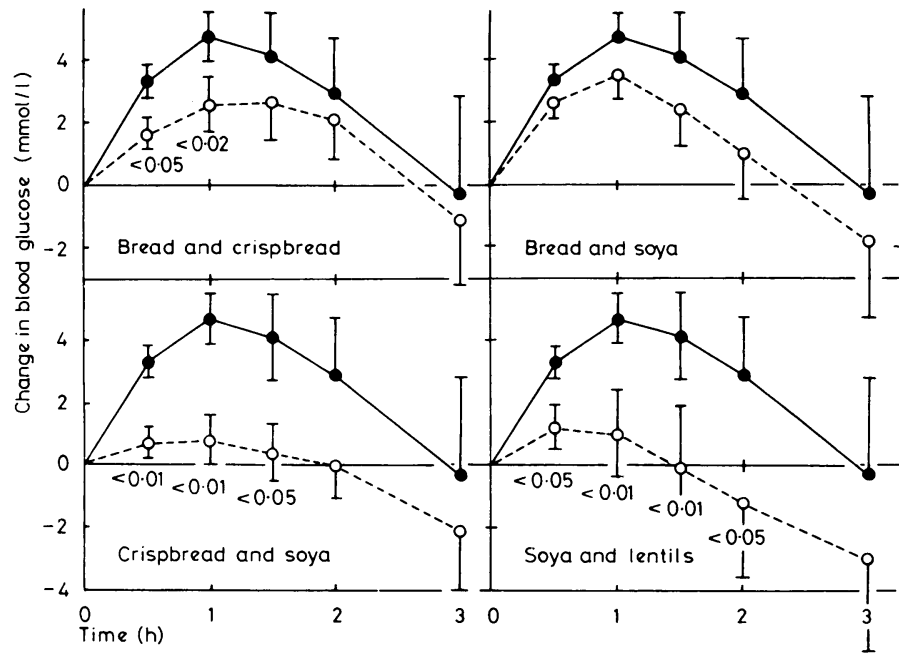

FIG $1-$ Mean ( \pm SEM) blood glucose response of six diabetics to guar and leguminous-seed breakfasts $\left(\mathrm{O}_{-}-\mathrm{O}\right)$ compared with response to bread and cheese breakfast (•- $\bullet$ ). For dietary composition of each breakfast see table I.

Conversion: SI to traditional units-Glucose: $1 \mathrm{mmol} / 1 \approx 18 \mathrm{mg} / 100 \mathrm{ml}$.

TABLE I-Mean compositions of seven breakfasts tested*

\begin{tabular}{|c|c|c|c|c|c|c|}
\hline & & & $\begin{array}{l}\text { Protein } \\
\text { (g) }\end{array}$ & $\begin{array}{l}\text { Fat } \\
\text { (g) }\end{array}$ & $\begin{array}{c}\text { Carbohydrate } \\
\text { (g) }\end{array}$ & $\begin{array}{c}\text { Dietary fibre } \\
(\mathbf{g})\end{array}$ \\
\hline 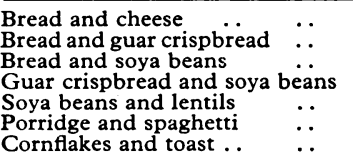 & $\begin{array}{l}\cdots \\
\cdots \\
\cdots \\
\cdots \\
\cdots\end{array}$ & $\begin{array}{l}\because \\
\because \\
\because \\
\cdots \\
\cdots\end{array}$ & $\begin{array}{r}35 \cdot 4 \pm 2 \cdot 3 \\
36 \cdot 5 \pm 4 \cdot 2 \\
36 \cdot 5 \pm 4 \cdot 2 \\
54 \cdot 5 \pm 8 \cdot 2 \\
38 \cdot 4 \pm 3 \cdot 9 \\
10 \cdot 2 \pm 0 \cdot 9 \\
9 \cdot 5 \pm 0 \cdot 5\end{array}$ & $\begin{array}{r}15 \cdot 6 \pm 1 \cdot 0 \\
18 \cdot 4 \pm 1 \cdot 8 \\
18 \cdot 5 \pm 1 \cdot 8 \\
19 \cdot 4 \pm 2 \cdot 9 \\
15 \cdot 6 \pm 1 \cdot 0 \\
6.4 \pm 0.5 \\
6.4 \pm 0.5\end{array}$ & $\begin{array}{l}42 \cdot 8 \pm 5 \cdot 3 \\
41 \cdot 9 \pm 5 \cdot 2 \\
41 \cdot 9 \pm 5 \cdot 2 \\
41 \cdot 9 \pm 5 \cdot 2 \\
42 \cdot 3 \pm 5 \cdot 2 \\
43 \cdot 8 \pm 7 \cdot 5 \\
43 \cdot 8 \pm 7 \cdot 5\end{array}$ & $\begin{array}{r}9 \cdot 0 \pm 1 \cdot 2 \\
12 \cdot 4 \pm 1 \cdot 5 \\
16 \cdot 5 \pm 2 \cdot 0 \\
19 \cdot 8 \pm 2 \cdot 9 \\
15 \cdot 5 \pm 1 \cdot 7 \\
4 \cdot 8 \pm 0 \cdot 8 \\
7 \cdot 7 \pm 1 \cdot 4\end{array}$ \\
\hline
\end{tabular}

*Calculated according to food tables."

TABLE II-Mean ( + SEM) data on six test meals, showing fasting blood glucose concentrations, insulin dose, body weight, and area under blood glucose response curve (expressed both as absolute value and as percentage of area under curve for bread and cheese meal)

\begin{tabular}{|c|c|c|c|c|c|c|}
\hline & & $\begin{array}{l}\text { Fasting blood } \\
\text { glucose } \\
(\mathrm{mmol} / \mathrm{l})\end{array}$ & $\begin{array}{l}\text { Insulin dose } \\
\text { (U/day) }\end{array}$ & $\begin{array}{l}\text { Body weight } \\
\text { (kg) }\end{array}$ & $\begin{array}{l}\text { 3-h glucose area } \\
(\mathrm{mmol} \mathrm{min/l)}\end{array}$ & $\begin{array}{c}\% \text { of bread } \\
\text { meal }\end{array}$ \\
\hline 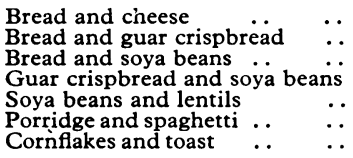 & $\begin{array}{l}\ldots \\
\cdots \\
\cdots \\
\cdots \\
\cdots\end{array}$ & $\begin{array}{l}11 \cdot 4 \pm 1 \cdot 7 \\
11 \cdot 8 \pm 1 \cdot 6 \\
11 \cdot 4 \pm 2 \cdot 1 \\
10 \cdot 3 \pm 2 \cdot 1 \\
11 \cdot 8 \pm 1 \cdot 9 \\
12 \cdot 9 \pm 2 \cdot 7 \\
12 \cdot 8 \pm 2 \cdot 9\end{array}$ & $\begin{array}{l}34 \pm 7 \\
31 \pm 5 \\
31 \pm 5 \\
34 \pm 7 \\
34 \pm 7 \\
39 \pm 8 \\
38 \pm 7\end{array}$ & $\begin{array}{l}58 \cdot 5 \pm 3 \cdot 4 \\
58 \cdot 4 \pm 3 \cdot 4 \\
58 \cdot 7 \pm 3 \cdot 3 \\
58 \cdot 9 \pm 3 \cdot 5 \\
58 \cdot 3 \pm 3 \cdot 5 \\
60 \cdot 3 \pm 5 \cdot 3 \\
61 \cdot 1 \pm 5 \cdot 7\end{array}$ & $\begin{array}{l}557 \pm 156^{*} \\
333 \pm 138^{*} \\
365 \pm 158^{*} \\
153 \pm 71^{*} \\
209 \pm 111^{*} \\
560 \pm 263 \dagger \\
552 \pm 20{ }^{\dagger}\end{array}$ & $\begin{array}{l}100 \\
51 \pm 16(\mathrm{p}<0.05) \\
65 \pm 13(\mathrm{p}<0.05) \\
25 \pm 8(\mathrm{p}<0.001) \\
29 \pm 11(\mathrm{p}<0.002) \\
95 \pm 49 \\
108 \pm 30\end{array}$ \\
\hline
\end{tabular}

$* \mathrm{n}=6 . \dagger \mathrm{n}=4$

Conversion: SI to traditional units-Glucose: $1 \mathrm{mmol} / 1 \approx 18 \mathrm{mg} / 100 \mathrm{ml}$

$\mathrm{mg} / 100 \mathrm{ml})$, insulin dose ( $31 \pm 5$ to $39 \pm 8 \mathrm{U} /$ day), and body weight $(58 \cdot 3+3 \cdot 5$ to $61 \cdot 1+5 \cdot 7 \mathrm{~kg})$ were similar. The slight increase in mean insulin dose and fasting blood glucose concentration seen before the porridge and cornflake breakfasts (table II) occurred because the subject with the lowest dose and fasting concentration did not take these meals.

Figures 1 and 2 show that the blood glucose concentrations measured after all except the porridge and cornflake breakfasts were below those measured after the wholemeal-bread breakfasts. The three-hour glucose areas show the same trend (table II) when expressed as a percentage of the area under the bread breakfast curve they show that a combination of soya beans and guar crispbread was the most effective in flattening the glycaemic response (to $25+8 \%$ of the area under the bread and cheese curve, $p<0.001$ ) followed by

\section{Discussion}

The present study shows that certain foods may be used in a meal to reduce the postprandial blood glucose response of diabetics. The results are similar to those seen with purified fibre formulations. In the present study there was an overall relation between glucose area expressed as a percentage of the area under the curve for wholemeal bread and the dietary fibre content ( $n=7, r=0.8696, p<0.02)$. This effect is weighted, however, by the high fibre content of the leguminous-seed meals. In a previous study, in which data on wholemeal bread compared with soya beans and lentils were presented, leguminous seeds were shown to be digested more slowly in vitro by human 
digestive juices than wholemeal bread. ${ }^{6}$ An increasing amount of data now suggests that dried leguminous seeds as a class are among the foods that cause the smallest change in blood glucose concentrations. ${ }^{7}$ Whether this is due to their fairly high fibre content, to the nature of the starch they contain, or perhaps to inhibitors of carbohydrate absorption is not clear.

Previous studies have shown that guar crispbread reduces the glycaemic response to carbohydrate ${ }^{8}$ Soya and lentils in normal subjects cause a low glycaemic response compared with cornflakes and wholemeal bread, which cause high responses. Spaghetti and porridge give intermediate rises. ${ }^{3} 9$

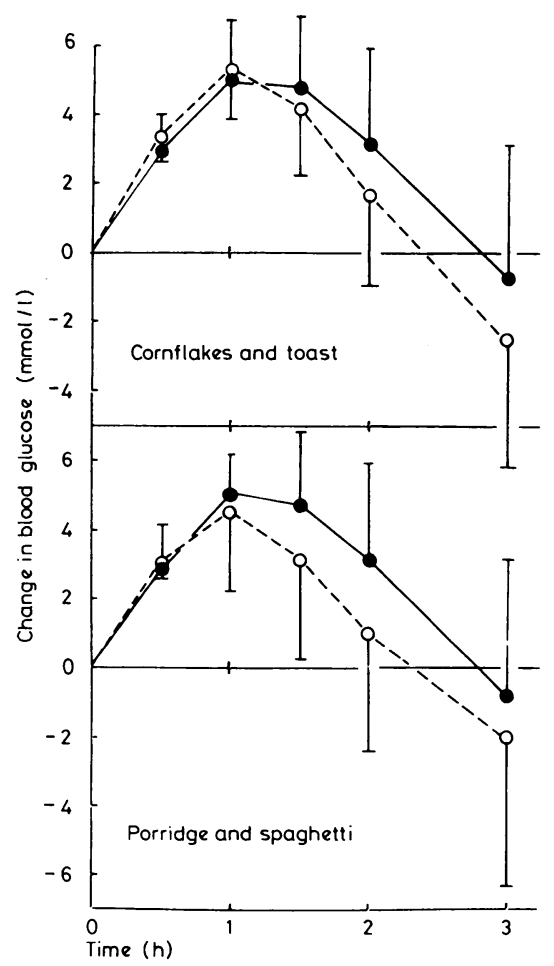

FIG 2-Mean ( \pm SEM) blood glucose response of four diabetics to cereal breakfasts ( $\mathrm{O}---\mathrm{O})$ compared with response to bread and cheese breakfast $(\bullet-\bullet)$. For dietary composition of each breakfast see table $I$.

Conversion: SI to traditional units-Glucose: 1 $\mathrm{mmol} / \mathrm{l} \approx 18 \mathrm{mg} / 100 \mathrm{ml}$

Guar, which itself is a leguminous seed fibre, flattens the glycaemic responses to mixed meals. ${ }^{10-12}$ Its mechanism of action appears to depend on reducing the rate of absorption as judged by studies using xylose ${ }^{13}$ and paracetamol ${ }^{14}$ as markers. Its effect on blood glucose concentration is independent of increased insulin secretion ${ }^{13}$ and in general depresses the postprandial responses of the hormones of the enteroinsular axis. ${ }^{13} 15$

Guar crispbread added to the diabetic diet in short-term studies reduced urinary glucose output ${ }^{16}$ and in long-term studies $^{17}$ also reduced the insulin requirement. This method of treatment has been criticised by workers who, through failing to mix the fibre with the food, ${ }^{12}$ have been unable to confirm the action of guar in test-meal and longer-term studies of diabetics. These workers have suggested that "natural" high-fibre foods may be both more acceptable and more effective than purified fibre preparations. The present study indicates that changes in cereal fibre content in terms of wholemeal bread, porridge, and cornflake breakfasts have little effect on the blood glucose response. Other studies have indicated a lack of effect of cereal fibre in improving glucose tolerance. ${ }^{13} 18$ Nevertheless, unprocessed cereal products are undoubtedly the most acceptable and readily available source of fibre in Western nutrition. Although leguminous seeds may be eaten in large quantities in poor communities, they are no longer common foods in the West and may prove difficult to reintroduce.

We conclude that although both purified fibre formulations and certain unprocessed foods may lower postprandial glycaemia in diabetics, the use of one need not necessarily mean the exclusion of the other. A combination of leguminous seed fibre preparations and whole leguminous seeds certainly increases effectiveness and may cut down on the total amount of each required to be taken and so increase acceptability for longterm inclusion in the diet.

We thank Dr Ewart Jepson and Dr Stuart McHardy-Young for permission to study their patients, and $\mathrm{Mr}$ John Still, $\mathrm{Mr}$ Adam Ritchie, Miss Christine Wilcox, Mrs Jacqueline Uddin, Mrs Patricia Walker, and Mrs Marie-Louise Beaumont for their enthusiastic collaboration.

DJAJ was in receipt of funds from the British Diabetic Association and the Medical Research Council.

\section{References}

1 Williams DRR, James WPT. Fibre and diabetes. Lancet $1979 ; \mathrm{i}: 271-2$

${ }^{2}$ Cohen M, Leong VW, Salmon E, Martin FIR. Role of guar and dietary fibre in the management of diabetes mellitus. Med f Aust 1980;1:59-61.

3 Jenkins DJA, Wolever TMS, Taylor RH, et al. Bioavailability to man of carbohydrate in foods. Proc Nutr Soc 1980;39:11A.

4 Paul AA, Southgate DAT. McCance and Widdowson's The composition of foods. London: HMSO, 1978. (Medical Research Council Special Report Series No 297.)

5 Clark LC Jr. A polarographic enzyme electrode for the measurement of oxidase substrates. In: Kessler M, Bruley DF, Leland CC, et al, eds. Oxygen supply. Munich: Urban and Schwarzenberg, 1973:120-8.

${ }^{6}$ Jenkins DJA, Wolever TMS, Taylor RH. et al. Rate of digestion of foods and postprandial glycaemia in normal and diabetic subjects. $\mathrm{Br}$ Med $\mathcal{F}$ $1980 ; 281: 14-7$.

7 Jenkins DJA, Wolever TMS, Taylor RH, Barker H, Fielden H. Exceptionally low blood glucose response to dried beans: comparison with other carbohydrate foods. $\mathrm{Br}$ Med f $1980 ; 281: 578-80$.

8 Jenkins DJA, Taylor RH, Nineham R, et al. Combined use of guar and acarbose in reduction of postprandial glycaemia. Lancet 1979 ;ii:924-7.

- Jenkins DJA, Wolever TMS, Taylor RH, et al. Glycaemic index of foods: a physiological basis for carbohydrate exchange. Am $\mathcal{F}$ Clin Nutr (in press).

10 Jenkins DJA, Leeds AR, Gassull MA, et al. Unabsorbable carbohydrates and diabetes: decreased post-prandial hyperglycaemia. Lancet 1976;ii: $172-4$

11 Goulder TJ, Alberti KGMM, Jenkins DJA. The effect of added fibre on the glucose and metabolic response to a mixed meal in normal and diabetic subjects. Diabetes Care 1978;1:351-5.

12 Tredger J, Wright J, Marks V. The effect of guar gum on blood alcoho levels following gin and tonic consumption. Proc Nutr Soc 1979;38: $70 \mathrm{~A}$.

13 Jenkins DJA, Wolever TMS, Leeds AR, et al. Dietary fibres, fibre analogues, and glucose tolerance: importance of viscosity. $\mathrm{Br} \mathrm{Med} \mathcal{F}$ 1978;i:1392-4.

${ }^{14}$ Holt S, Heading RC, Carter DC, Prescott LF, Tothill P. Effect of gel fibre on gastric emptying and absorption of glucose and paracetamol. Lancer $1979 ; \mathrm{i}: 636-9$.

15 Morgan LM, Goulder TJ, Tsioladis D, Marks V, Alberti KGMM. The effect of unabsorbable carbohydrate on gut hormones: modification of postprandial GIP secretion by guar. Diabetologia 1979;17:85-9.

16 Jenkins DJA, Wolever TMS, Hockaday TDR, et al. Treatment of diabetes with guar gum. Lancet 1977 ;ii:779-80.

17 Jenkins DJA, Wolever TMS, Taylor RH, Reynolds D, Nineham $\mathbf{R}$ Hockaday TDR. Diabetic glucose control, lipids, and trace elements on long-term guar. Br Med f 1980;280:1353-4.

18 O'Dea K, Nestel PJ, Antonoff L. Physical factors influencing postprandia glucose and insulin responses to starch. Am $\mathcal{f}$ Clin Nutr 1980:33:760-5.

(Accepted 26 September 1980)

\section{Correction}

\section{Response of antidiuretic hormone to chlorpropamide}

We regret that an error occurred in this paper by Dr M C Champion and others (6 September, p 645). The units for plasma concentrations of antidiuretic hormone should have read $\mathrm{ng} / \mathrm{l}$, not $\mu \mathrm{g} / \mathrm{l}$. 